\title{
Effect of Fusarium Head Blight Management Practices on Mycotoxin Contamination of Wheat Straw
}

Kaitlyn M. Bissonnette, Frederic L. Kolb, and Keith A. Ames, Department of Crop Sciences, University of Illinois, Urbana 61801; and Carl A. Bradley, ${ }^{\dagger}$ Department of Plant Pathology, University of Kentucky Research and Education Center, Princeton 42445

\begin{abstract}
Management of Fusarium graminearum-associated mycotoxins in wheat grain has been extensively evaluated, but little is known about management of mycotoxins in straw. Two research trials were conducted at four locations from 2011 to 2014 . The objective of the first trial was to determine the efficacy of fungicides, and the objective of the second trial was to evaluate the use of integrated disease management strategies, for the control of Fusarium head blight (FHB) and reducing the concentration of the Fusarium mycotoxins deoxynivalenol, 3-acetyldeoxynivalenol, and 15-acetyl-deoxynivalenol in straw. In the first trial, it was determined that demethylation inhibitor (DMI) fungicides did not offer significant $(P \leq 0.05)$ reductions of mycotoxin concentrations in

the straw compared with a no-fungicide control treatment, but significant $(P \leq 0.05)$ reductions in mycotoxin concentration were observed in the control when compared with treatments with the application of quinone outside inhibitor (QoI)-containing fungicides. In the second trial, mycotoxin concentrations in the straw were significantly $(P \leq 0.05)$ reduced in the moderately resistant cultivar compared with the susceptible cultivar, but were not affected by the use of a fungicide. The practices typically used to manage Fusarium mycotoxins in wheat grain, especially the selection of resistant cultivars and not using a QoI fungicide, may be an effective means to reduce mycotoxin concentrations in the straw.
\end{abstract}

Fusarium head blight (FHB) has been responsible for millions of dollars in damage to cereal crops worldwide. Fusarium graminearum is the primary pathogen responsible for FHB in the Midwestern United States (Sutton 1982) and is known to produce several mycotoxins that are detrimental to both human and animal health (Shaner 2003). Deoxynivalenol (DON) is the most common mycotoxin associated with grain contaminated by $F$. graminearum. DON is a potent inhibitor of protein synthesis (Cundliffe et al. 1974; Cundliffe and Davies 1977) and is considered to be a pathogenicity factor for infection by $F$. graminearum (Harris et al. 1999). The acetylated derivatives of DON, 3-acetyl-deoxynivalenol (3ADON), and 15-acetyl-deoxynivalenol (15ADON) are produced in conjunction with DON and are defined as an isolate's chemotype. F. graminearum isolates in North America belong predominantly to the $15 \mathrm{ADON}$ chemotype, but in the preceding decade, isolates of the 3ADON chemotype, which are capable of producing up to four times as much total DON as the 15ADON chemotype, have been recovered in portions of Canada and in the Upper Midwestern states (Puri and Zhong 2010; Ward et al. 2008). Additionally, nivalenol (NIV) and zearleone (ZEA) are mycotoxins that are associated with $F$. graminearum, but their presence and impacts on production agriculture in the Midwest are largely unknown (Gale et al. 2011; Mirocha et al. 1967). The mycotoxins produced by $F$. graminearum, along with the presence of shriveled, Fusariumdamaged kernels, are associated with quality loss and discounts at grain elevators throughout the region (Salgado et al. 2014).

Effective management is essential for the control of the mycotoxins produced by Fusarium spp. associated with FHB in wheat heads. Fungicide applications have been studied primarily for their impacts on DON accumulation in grain, but it is not well understood how these applications impact the levels of mycotoxins in the straw.

${ }^{\dagger}$ Corresponding author: C. A. Bradley; E-mail: carl.bradley@uky.edu.

Funding: USDA Agricultural Research Service (59-0206-9-076). This is a cooperative project with the U.S. Wheat \& Barley Scab Initiative.

Current address of K. M. Bissonnette: Division of Plant Sciences, University of Missouri, Columbia, MO 65211.

Accepted for publication 5 January 2018

C 2018 The American Phytopathological Society
Research has focused largely on the use of the demethylation inhibitor (DMI) class of fungicides applied at anthesis (Feekes growth stage 10.5.1 [Large 1954]), as an effective means to control FHB and associated mycotoxins in the grain (Boyacioglu et al. 1992; Cromey et al. 2001; Mesterházy and Bartók 1996). Research also has shown that the DMI class of fungicides is more effective at controlling the pathogens of FHB and their associated mycotoxins in the grain than fungicides in the quinone outside inhibitor (QoI) class (Amarasinghe et al. 2013; Haidukowski et al. 2005; Magan et al. 2002; Pirgozliev et al. 2002; Simpson et al. 2001). It has been consistently observed that a QoI fungicide, alone or as part of a mixture, when applied to wheat in the boot stage through anthesis, has the potential to increase DON concentration in the grain (Blandino et al. 2006; Chala et al. 2003; Cromey et al. 2002; Pirgozliev et al. 2002). This is typically not observed when DMI fungicides are used alone. Paul et al. (2008) evaluated the impacts of many of the current DMI fungicides that are used to control FHB. The results of that analysis showed that metconazole (Caramba; BASF Corp.; Research Triangle Park, NC), prothioconazole (Proline; Bayer CropScience; Research Triangle Park, NC), and tebuconazole + prothioconazole (Prosaro; Bayer CropScience) offered the best control of FHB and DON concentration in grain.

In years when inoculum levels are high or when environmental conditions are ideal for the establishment of disease at epidemic levels, fungicide applications may not be sufficient to adequately control FHB and associated mycotoxins (Paul et al. 2010). It is recommended that multiple disease management approaches be integrated by selecting cultivars with resistance to $\mathrm{FHB}$, changing or managing cultural practices such as tillage and crop rotation, and applying an effective fungicide at the proper time (Haidukowski et al. 2005). Several studies support the idea that integrating the use of a cultivar with moderate resistance to FHB with the application of an effective DMI fungicide allows for the best control of DON accumulation in the grain (Blandino et al. 2012; McMullen et al. 2008; Willyerd et al. 2012).

DON does not accumulate uniformly throughout the head. DON concentration has been reported to be four to 10 times higher in the chaff and rachis than in the grain (Miller et al. 1985; Rottinghaus et al. 2009). In recent years, Fusarium mycotoxins have also been reported to accumulate in the straw associated with contaminated grain (Brinkmeyer et al. 2006; Cowger and Arellano 2013; Rohweder et al. 2011, 2013; Rottinghaus et al. 2009). Since DON and its derivatives are water soluble, this accumulation of mycotoxins in the stem could be associated with late season free moisture events, such as rain or overhead irrigation, where DON is leached out of the infected head 
(Gautam and Dill-Macky 2012). Several of these studies have focused on the presence of Fusarium mycotoxins in the straw in relation to swine and other livestock production (Häggblom and Nordkvist 2015; Nordkvist and Häggblom 2014; Rohweder et al. 2011, 2013). Wheat straw is commonly used as bedding material for swine, and the consumption of bedding can account for up to $13 \%$ of their diet (van Barneveld et al. 2005). When swine ingest DON or nivalenol, they exhibit symptoms of feed refusal, poor weight gain, and, in extreme cases, female reproductive problems (Marasas et al. 1979; Mirocha et al. 1967; Vesonder and Hesseltine 1981). These studies have reinforced the importance of studying the presence of mycotoxins in wheat straw for livestock, especially swine and other nonruminant animals that are sensitive to these mycotoxins. Though informative, they have not effectively addressed how to best control the accumulation of these mycotoxins in the straw.

Fungicide application and integrated disease management evaluations of FHB control measures have focused on DON concentration in the grain. To our knowledge, how these practices impact the levels of Fusarium mycotoxins in straw has not been studied. Our objective in this study was to determine the effect of the FHB management practices of foliar fungicide application and planting resistant cultivars on the concentrations of $F$. graminearum mycotoxins in wheat straw.

\section{Materials and Methods}

Fungicide trial. Field trials were conducted to evaluate the effects of different foliar fungicides on the concentration of Fusarium mycotoxins in straw of a FHB-susceptible soft red winter wheat cultivar, Pioneer Brand 25R47. In total, 16 fungicide efficacy trials were conducted from 2011 to 2014. Each year of the trial, five fungicide treatments and a nontreated control were evaluated. Fungicide treatments included three products that were made up of DMI fungicide active ingredients applied at Feekes growth stage 10.5.1, and were metconazole (Caramba; BASF Corp.) applied at $0.09 \mathrm{~kg}$ a.i./ha, prothioconazole + tebuconazole (Prosaro; Bayer CropScience) applied at $0.10+0.10 \mathrm{~kg}$ a.i./ha, and tebuconazole (Folicur; Bayer CropScience; or Monsoon; Loveland Products, Inc., Greely, CO) applied at $0.13 \mathrm{~kg}$ a.i./ha. Each year, a fungicide product that contained a QoI fungicide applied at Feekes growth stage 9 also was evaluated. The QoI-containing treatments evaluated were pyraclostrobin (Headline; BASF Corp.) applied at $0.11 \mathrm{~kg}$ a.i./ha in 2011 and 2012, pyracostrobin + fluxapyroxad (Priaxor; BASF Corp.) applied at $0.10+$ $0.05 \mathrm{~kg}$ a.i./ha in 2013, and picoxystrobin (Aproach; DuPont Crop Protection, Wilmington, DE) applied at $0.13 \mathrm{~kg}$ a.i./ha in 2014.
Fungicides were applied with a $\mathrm{CO}_{2}$-pressurized backpack sprayer calibrated to deliver 187 liters/ha at a pressure of $276 \mathrm{kPA}$ through TwinJet TJ60-8002 nozzle tips (Spraying Systems Co.; Wheaton, IL). A nonionic surfactant (Induce; Helena Chemical Company, Collierville, TN) at $0.125 \% \mathrm{v} / \mathrm{v}$ was added to each spray mixture. A nontreated (no fungicide) control was also included. This trial was conducted at four locations each year in 2011 through 2014. The trials were located at University of Illinois research farms located near Brownstown, Dixon Springs, Monmouth, and Urbana, IL. Information about the trials at each location can be found in Table 1. Trials were grown using recommended management practices (Nafziger 2009). Six row plots were planted at a seeding rate of 2.5 to 3.7 million plants/ha with $0.2 \mathrm{~m}$ row spacing and were $1.2 \mathrm{~m}$ long. Plots were arranged in a randomized complete block design and replicated four times. To help ensure $F$. graminearum infection and FHB development, wheat was planted directly into corn (Zea mays) stubble and mistirrigated. Mist-irrigation was applied six times per day for $15 \mathrm{~min}$ beginning 2 weeks prior to anthesis and continuing until Feekes growth stage 11.2. Plots at the Monmouth location in 2014 were abandoned due to excessive winter kill throughout the trial.

Integrated management trial. Another study focused on integrated FHB management practices by comparing either the application of prothioconazole + tebuconazole (Prosaro; Bayer CropScience) applied at $0.10+0.10 \mathrm{~kg}$ a.i./ha at Feekes 10.5 .1 growth stage with Induce (Helena Chemical Company) nonionic surfactant at $0.125 \% \mathrm{v} / \mathrm{v}$ or no fungicide to a soft red winter wheat cultivar that was either moderately resistant (cv. IL02-18228) or very susceptible (cv. Pioneer Brand 25R47) to FHB. The fungicide treatment was applied as described above. This study was conducted at three locations that relied on natural rainfall (Dixon Springs, Monmouth, and Urbana) and a fourth location that was mist-irrigated in Urbana. Information about the trials at each location can be found in Table 1 . The mist-irrigation system was conducted using the same procedures as described above. At each location, the trial was arranged in a split plot design with the main plot as cultivar and the subplot as the fungicide treatment and was planted as described above. Each cultivar (moderately resistant or very susceptible) $\times$ fungicide (fungicide or no fungicide) combination was replicated four times. The Monmouth location was abandoned in 2014 due to excessive winterkill throughout the trial.

Fusarium head blight index and yield. Plot incidence of FHB (\% of plants with symptoms) and FHB severity (\% head area affected) data were collected in each trial at soft dough stage (Feekes 11.2). Trials were harvested in July of 2011 through 2014 with a Kincaid 8-XP research plot combine (Kincaid Equipment Manufacturing,

Table 1. Mist irrigation, soil type, planting date, anthesis date, harvest date, and rainfall information for the fungicide (F) and integrated management (IM) trials conducted in Illinois

\begin{tabular}{|c|c|c|c|c|c|c|c|}
\hline Year, location & $\begin{array}{c}\text { Trial } \\
\text { (F/IM) }\end{array}$ & $\begin{array}{l}\text { Trial(s) mist-irrigated } \\
(\text { F/IM) }\end{array}$ & Soil type & $\begin{array}{c}\text { Planting } \\
\text { date }\end{array}$ & $\begin{array}{l}\text { Anthesis } \\
\text { date }\end{array}$ & $\begin{array}{c}\text { Harvest } \\
\text { date }\end{array}$ & $\begin{array}{c}\text { Rainfall } 1 \\
\text { April - 30 June } \\
\text { (cm) }\end{array}$ \\
\hline 2011, Brownstown & $\mathrm{F}$ & $\mathrm{F}$ & Cisne silt loam & $10 / 9 / 2010$ & $5 / 19 / 2011$ & 7/2/2011 & 68.0 \\
\hline 2011, Dixon Springs & $\mathrm{F}, \mathrm{IM}$ & $\mathrm{F}$ & Grantsburg silt loam & $10 / 10 / 2010$ & $5 / 10 / 2011$ & $7 / 5 / 2011$ & 70.1 \\
\hline 2011, Monmouth & $\mathrm{F}, \mathrm{IM}$ & $\mathrm{F}$ & Osco silt loam & $10 / 1 / 2010$ & $5 / 25 / 2011$ & $6 / 30 / 2011$ & 38.3 \\
\hline 2011, Urbana & $\mathrm{F}, \mathrm{IM}$ & $\mathrm{F}$ & Drummer silty clay & $10 / 2 / 2010$ & $5 / 23 / 2011$ & $6 / 29 / 2011$ & 42.5 \\
\hline 2011, Urbana & IM & IM & Flanagan silt loam & $9 / 29 / 2010$ & $5 / 22 / 2011$ & $7 / 2 / 2011$ & 43.2 \\
\hline 2012, Brownstown & $\mathrm{F}$ & $\mathrm{F}$ & Cisne silt loam & $10 / 10 / 2011$ & $4 / 28 / 2012$ & $6 / 13 / 2012$ & 23.4 \\
\hline 2012, Dixon Springs & $\mathrm{F}, \mathrm{IM}$ & $\mathrm{F}$ & Grantsburg silt loam & $10 / 12 / 2011$ & $4 / 19 / 2012$ & $6 / 7 / 2012$ & 8.1 \\
\hline 2012, Monmouth & $\mathrm{F}, \mathrm{IM}$ & $\mathrm{F}$ & Osco silt loam & $10 / 1 / 2011$ & $5 / 8 / 2012$ & $6 / 25 / 2012$ & 20.8 \\
\hline 2012, Urbana & $\mathrm{F}, \mathrm{IM}$ & $\mathrm{F}$ & Drummer silty clay & $10 / 10 / 2011$ & $5 / 3 / 2012$ & $6 / 27 / 2012$ & 19.5 \\
\hline 2012, Urbana & IM & IM & Flanagan silt loam & $10 / 3 / 2011$ & $4 / 30 / 2012$ & $6 / 25 / 2012$ & 17.0 \\
\hline 2013, Brownstown & $\mathrm{F}$ & $\mathrm{F}$ & Cisne silt loam & $10 / 8 / 2012$ & $5 / 18 / 2013$ & $7 / 1 / 2013$ & 53.1 \\
\hline 2013, Dixon Springs & $\mathrm{F}, \mathrm{IM}$ & $\mathrm{F}$ & Grantsburg silt loam & $10 / 10 / 2012$ & $5 / 12 / 2013$ & $6 / 28 / 2013$ & 31.3 \\
\hline 2013, Monmouth & $\mathrm{F}, \mathrm{IM}$ & $\mathrm{F}$ & Osco silt loam & $10 / 1 / 2012$ & $5 / 27 / 2013$ & $7 / 10 / 2013$ & 50.1 \\
\hline 2013, Urbana & $\mathrm{F}, \mathrm{IM}$ & $\mathrm{F}$ & Drummer silty clay & $10 / 11 / 2012$ & $5 / 23 / 2013$ & $7 / 15 / 2013$ & 45.4 \\
\hline 2013, Urbana & IM & IM & Flanagan silt loam & $10 / 9 / 2012$ & $5 / 21 / 2013$ & $7 / 3 / 2013$ & 34.5 \\
\hline 2014, Brownstown & $\mathrm{F}$ & $\mathrm{F}$ & Cisne silt loam & $10 / 13 / 2013$ & $5 / 19 / 2014$ & $6 / 25 / 2014$ & 37.6 \\
\hline 2014, Dixon Springs & $\mathrm{F}, \mathrm{IM}$ & $\mathrm{F}$ & Grantsburg silt loam & $10 / 25 / 2013$ & $5 / 12 / 2014$ & $6 / 30 / 2014$ & 43.2 \\
\hline 2014, Urbana & $\mathrm{F}, \mathrm{IM}$ & $\mathrm{F}$ & Drummer silty clay & $10 / 2 / 2013$ & $5 / 28 / 2014$ & $7 / 7 / 2014$ & 42.9 \\
\hline 2014, Urbana & IM & IM & Flanagan silt loam & $10 / 10 / 2013$ & $5 / 30 / 2014$ & $7 / 3 / 2014$ & 38.5 \\
\hline
\end{tabular}


Haven, KS), and yields were calculated and converted to $\mathrm{kg} / \mathrm{ha}$. At harvest, the combine was adjusted to cut the straw $25 \mathrm{~cm}$ above the ground to preserve the lower portion of the straw for mycotoxin analysis. FHB index was calculated using the equation, FHB index = (incidence $\times$ severity) $/ 100$.

Straw collection. For each plot at all locations, the bottom $25 \mathrm{~cm}$ of straw was collected within 3 days of harvest. After harvest, the straw from a $0.6 \mathrm{~m}$ section in the center of each plot was hand cut at the soil line, and the top was trimmed to approximately $25 \mathrm{~cm}$. Leaf and other plant material, such as chaff and other head material, were removed, and stems were dried with forced air at $32^{\circ} \mathrm{C}$ for 7 days. After drying, $50 \mathrm{~g}$ of stem material from each plot were ground with a microfine grinder (IKA Works, Inc., Wilmington, NC).

Mycotoxin analysis. Straw and grain samples were assayed for concentrations of DON, 3ADON, 15ADON, nivalenol (NIV), and zearalenone (ZEA) by methods modified from Tanaka et al. (2006). Four grams of ground sample was extracted with $16 \mathrm{ml}$ of acetonitrile/ water $(84 / 16, v / v)$. The sample was placed on a shaker for $1 \mathrm{~h}$, and then $4 \mathrm{ml}$ of extract was passed through a column packed with C18 and aluminum oxide $(1 / 3, w / w)$. One milliliter of the filtrate was evaporated to dryness under nitrogen at room temperature and derivatized by silylating reagent (TMSI/TMCS, 100/1) for GC-MS analyses (Shimadzu GCMS-QP2010; Shimadzu Corp., Kyoto, Japan). In all four years, straw was tested for all five mycotoxins for both field trials. Grain was only tested for DON. All mycotoxin testing was conducted at the University of Minnesota mycotoxin testing laboratory in St. Paul, MN.

Statistical analysis. Mycotoxin concentration data were logtransformed $(\log \mathrm{DON}=\log [\mathrm{DON}+1], \log 3 \mathrm{ADON}=\log [3 \mathrm{ADON}+1]$, $\log 15 \mathrm{ADON}=\log [15 \mathrm{ADON}+1], \log \mathrm{NIV}=\log [\mathrm{NIV}+1]$, and $\log \mathrm{ZEA}=$ $\log [\mathrm{ZEA}+1])$ to homogenize the variances and correct for zeros present in the data set. To standardize the yield in each plot, the data were corrected to a $13.5 \%$ moisture concentration. The data were then analyzed with SAS software (SAS version 9.4, SAS Institute Inc., Cary, NC) using the mixed models procedure (PROC MIXED) with year, location, and block as random effects. Treatment (fungicide for the fungicide trial) or cultivar, fungicide, and the cultivar $\times$ fungicide interaction (for the integrated management trial) were treated as fixed effects. The interaction of year $\times$ location $\times$ treatment was not significant $(P \leq 0.05)$ in the fungicide trial, nor were the interactions of year $\times$ fungicide, location $\times$ cultivar, location $\times$ fungicide, year $\times$ location $\times$ fungicide, or year $\times$ location $\times$ cultivar $\times$ fungicide interactions significant $(P \leq 0.05)$ in the integrated management trial, and were removed from their respective models. Best linear unbiased predictors (BLUPs) were written to estimate the random effects of each model. Spearman correlation analyses were performed using PROC CORR SPEARMAN to correct for missing data points and the non-normal distribution of the data. Significant differences were determined using Tukey's W procedure with $\alpha=0.05$.

\section{Results}

Fungicide trial. The environment contributed significantly $(P \leq$ $0.05)$ to the variability of the model with a significant interaction of year $\times$ location observed for both grain and straw samples for all mycotoxins and for yield and FHB index. The interaction of treatment $\times$ year, also attributed to the environment, was significant, but only for $3 \mathrm{ADON}$ in the straw. Though the environment significantly contributed to the variability of the model, the focus of this trial was on the effects of fungicide on mycotoxin concentrations in the straw, and therefore the main effect of treatment will be the focus of the analyses. Statistical analysis revealed significant $(P \leq 0.05)$ differences among some, but not all, of the fungicide treatments for mycotoxin concentrations in the straw (Table 2).

Significantly $(P \leq 0.05)$ greater DON concentration was observed in the straw from the plots treated with a QoI-containing fungicide compared with straw from the plots in which either tebuconazole or tebuconazole + prothioconazole were applied (Fig. 1). However, DON concentrations from the QoI-treated plots did not significantly differ from DON levels in nontreated control plots or plots treated with metconazole. Significant DON reductions in the straw were also not observed in the plots treated with any of the three DMI fungicides when compared with DON concentrations in the nontreated control plots.

The concentrations of $3 \mathrm{ADON}$ and $15 \mathrm{ADON}$ were much lower than the concentration of DON in the straw (Fig. 1). Significantly

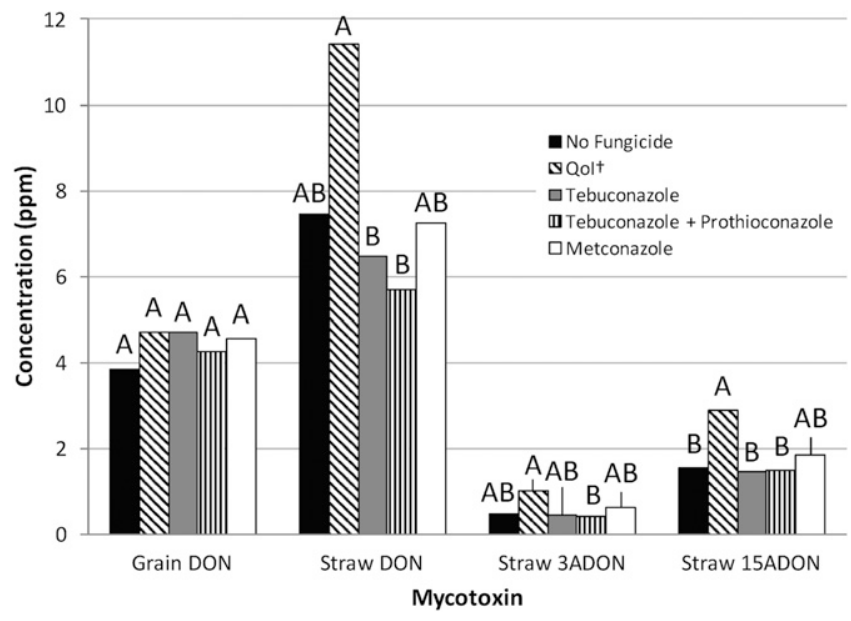

Fig. 1. Estimated mycotoxin concentrations in the straw and grain reported as parts per million (ppm) across all years of the fungicide study. Values are the backtransformed concentrations for each mycotoxin in the indicated plant material. Letters indicate significant differences between treatments for each mycotoxin using Tukey's W test with $\alpha=0.05 .{ }^{\dagger}$ Qol fungicides used included Headline (Pyraclostrobin) in 2011 and 2012, Priaxor (Pyraclostrobin + Fluxapyroxad [Qol + SDHI]) in 2013, and Aproach (Picoxystrobin) in 2014.

Table 2. Analysis of variance results for the fungicide trials for four fungicide treatments (three demethylation inhibitor fungicides and one quinone outside inhibitor-containing fungicide) and a nontreated (no-fungicide) control on Fusarium head blight (FHB) control in a susceptible soft red winter wheat cultivar at four field locations in Illinois from 2011 through 2014. Trial results are reported as probabilities for all model effects and interactions for the concentrations of Fusarium mycotoxins deoxynivalenol (DON), 3-acetyl-DON, 15-acetyl-DON, nivalenol, and zearalenone reported in the straw and grain and the FHB index and yield.

\begin{tabular}{|c|c|c|c|c|c|c|c|c|c|c|}
\hline \multirow[b]{2}{*}{ Effect } & & \multirow[b]{2}{*}{ df } & \multicolumn{2}{|c|}{$\begin{array}{c}\text { Deoxynivalenol } \\
\text { (DON) }\end{array}$} & \multirow{2}{*}{$\frac{\text { 3-acetyl-DON }}{\text { Straw }}$} & \multirow{2}{*}{$\frac{\text { 15-acetyl-DON }}{\text { Straw }}$} & \multirow{2}{*}{$\frac{\text { Nivalenol }}{\text { Straw }}$} & \multirow{2}{*}{$\frac{\text { Zearalenone }}{\text { Straw }}$} & \multirow[b]{2}{*}{ Index ${ }^{a}$} & \multirow[b]{2}{*}{ Yield } \\
\hline & & & Grain & Straw & & & & & & \\
\hline $\operatorname{Trt}^{\mathrm{b}}$ & $P>F$ & 4 & 0.19 & 0.02 & 0.03 & 0.01 & 0.45 & 0.59 & 0.88 & 0.93 \\
\hline Year & $P>F$ & 3 & 0.27 & 1.00 & 0.74 & 0.90 & $\mathrm{NE}^{\mathrm{c}}$ & 1.00 & 0.93 & 0.003 \\
\hline Location & $P>F$ & 3 & $\mathrm{NE}$ & 0.97 & 0.54 & 0.82 & 0.90 & 0.97 & NE & $\mathrm{NE}$ \\
\hline Location $\times$ year & $P>F$ & 9 & $<0.0001$ & $<0.0001$ & $<0.0001$ & 0.0001 & 0.02 & $<0.0001$ & $<0.0001$ & $<0.0001$ \\
\hline Trt $\times$ location & $P>F$ & 12 & 1.00 & 0.43 & 0.12 & 1.00 & 0.82 & $\mathrm{NE}$ & $\mathrm{NE}$ & 0.88 \\
\hline Trt $\times$ year & $P>F$ & 12 & 0.96 & 0.90 & 0.0006 & 0.39 & $\mathrm{NE}$ & 0.99 & 0.98 & 0.56 \\
\hline
\end{tabular}

\footnotetext{
${ }^{\mathrm{a}}$ Index was calculated by (FHB incidence $\times$ FHB severity) / 100

${ }^{\mathrm{b}}$ Fungicide treatment.
}

${ }^{\mathrm{c}}$ Not estimable: did not contribute to the variability of the model. 
$(P \leq 0.05)$ higher levels of $3 \mathrm{ADON}$ were detected in straw samples from QoI fungicide-treated plots as compared with levels detected in straw samples from tebuconazole + prothioconazole-treated plots. No other significant differences in $3 \mathrm{ADON}$ were detected. Significantly greater $15 \mathrm{ADON}$ concentrations were detected in the straw of QoI fungicide-treated plots compared with the DON concentrations observed in plots treated with no fungicide, tebuconazole, or tebuconazole + prothioconazole. No other significant differences in $15 \mathrm{ADON}$ concentration were detected.

Only the interaction of year $\times$ location was significant for NIV $(P=0.02)$ and ZEA $(P<0.0001)$ concentrations in the straw (Table 2). There were no significant differences observed among treatments for NIV or ZEA concentration in the straw. These mycotoxins, though detected, were not consistently present at all locations or in all years.

The DON concentrations detected in the grain were significantly and positively correlated to straw concentrations of DON $(P<0.0001)$, $3 \mathrm{ADON}(P<0.0001)$, and $15 \mathrm{ADON}(P<0.0001)$ (Table 3$)$. A significant $(P<0.0001)$ positive correlation between DON concentration in the grain and FHB index was also observed. The FHB index also was significantly and positively correlated with the DON $(P<0.0001)$, $3 \mathrm{ADON}(P<0.0001)$, and 15ADON $(P<0.0001)$ concentrations detected in the straw. The correlation between DON concentration in the grain versus yield, and $3 \mathrm{ADON}$ concentration in the straw versus yield were significant $(P=0.0007$ and $P=0.01$, respectively) and negative.

Integrated disease management trial. The environmental interaction of year $\times$ location was significant for DON concentration in the grain $(P=0.05)$, and DON $(P=0.0001), 3$ ADON $(P=0.006)$, and 15ADON $(P=0.01)$ concentration in the straw (Table 4). The three-way interaction of year $\times$ location $\times$ cultivar was also

Table 3. Results of a Spearman correlation analysis for the fungicide trial showing the correlation coefficients and probabilities of the correlations between the deoxynivalenol (DON), 3-acetyl-DON, and 15-acetyl-DON concentrations reported in wheat straw with the DON concentrations in the grain, the Fusarium head blight (FHB) index value, and the yield levels in the fungicide study. Correlations between the DON concentrations in the grain and the FHB index and yield are also listed.

\begin{tabular}{|c|c|c|c|c|c|}
\hline & & \multicolumn{2}{|c|}{$\begin{array}{l}\text { Deoxynivalenol } \\
\text { (DON) }\end{array}$} & \multirow{2}{*}{$\begin{array}{c}\begin{array}{c}\text { 3-acetyl- } \\
\text { DON }\end{array} \\
\text { Straw }\end{array}$} & \multirow{2}{*}{$\begin{array}{c}\begin{array}{c}\text { 15-acetyl- } \\
\text { DON }\end{array} \\
\text { Straw }\end{array}$} \\
\hline & & Grain & Straw & & \\
\hline \multirow[t]{2}{*}{ Grain DON } & $\mathrm{R}$ & - & 0.55 & 0.47 & 0.53 \\
\hline & Prob $>|r|$ & - & $<0.0001$ & $<0.0001$ & $<0.0001$ \\
\hline \multirow[t]{2}{*}{ Index ${ }^{a}$} & $\mathrm{R}$ & 0.54 & 0.16 & 0.08 & 0.14 \\
\hline & Prob $>|r|$ & $<0.0001$ & 0.006 & 0.16 & 0.01 \\
\hline \multirow[t]{2}{*}{ Yield } & $\mathrm{R}$ & -0.80 & -0.45 & -0.36 & -0.37 \\
\hline & Prob $>|r|$ & $<0.0001$ & $<0.0001$ & $<0.0001$ & $<0.0001$ \\
\hline
\end{tabular}

${ }^{a}$ Index was calculated by (FHB incidence $\times$ FHB severity) $/ 100$. significant for DON concentration in the grain $(P=0.0001)$ and yield $(P<0.0001)$. When partitioned by cultivar, the year $\times$ location did not significantly differ within a cultivar, indicating that the environment was not a significant contributor to the total DON concentration or yield. Therefore, for the purpose of discussing the results of the data, the main effect of cultivar will be discussed separately from the year $\times$ location interaction for DON in the grain.

The three way interaction of year $\times$ cultivar $x$ fungicide was also significant, but only for $3 \mathrm{ADON}$ in the straw $(P=0.01)$ and FHB in$\operatorname{dex}(P=0.0004)$. When this interaction was partitioned by cultivar level and by fungicide level, no significant differences were observed across years, and therefore the focus of the analysis for $3 \mathrm{ADON}$ in the straw and FHB index will be the cultivar $\times$ fungicide interaction and main effects. No other interactions were significant in the grain or straw for any mycotoxin or for FHB index or yield.

The cultivar $x$ fungicide interaction was not significant for any mycotoxin in the grain or straw, or for FHB index or yield. In regards to the main effects, significant differences between cultivars were observed for DON concentration in the grain $(P=0.05)$, and DON $(P=0.02)$ and $15 \mathrm{ADON}(P=0.02)$ concentration in the straw (Fig. 2). However, there were no significant differences observed between fungicide treatments for any mycotoxin in the grain or the straw, or for FHB index or yield.

NIV and ZEA concentrations were also detected in the straw but were not consistently present at all locations or in all years. No significant differences among treatments were observed for either mycotoxin for the main effects or for any interactions.

Significant, positive correlations between DON concentration in the grain and mycotoxin concentration in the straw were detected (Table 5). Concentrations of DON, 3ADON, and 15ADON in the straw and in the grain showed a significant, positive correlation with FHB index. There also was a significant, negative correlation between DON in the grain and yield $(P=0.0007, \mathrm{R}=-0.23)$, and a significant, negative correlation between $3 \mathrm{ADON}$ and yield $(P=0.01$, $\mathrm{R}=-0.17$ ) in the straw.

\section{Discussion}

Based on the results of this study, high concentrations ( $>2 \mathrm{ppm}$ ) of DON can be detected in wheat straw after harvest, even when adequate control measures for FHB and DON reduction in the grain are used. Although vital for the control of DON in grain during years with high inoculum levels and optimal weather conditions for disease development, fungicides may not translate to adequate reductions in DON concentration in the straw, especially on cultivars susceptible to FHB. Salgado et al. (2014) emphasized that, when applying fungicides for FHB control, there is a need for significant reductions in mycotoxin concentrations and significant yield increases for these applications to be of maximum economic benefit in grain production. This can also be said for minimizing DON in wheat straw in order

Table 4. Analysis of variance results for the integrated disease management trials for two levels of fungicide application (demethylation inhibitor fungicide or no fungicide) and two levels of cultivar susceptibility to Fusarium head blight (FHB) (susceptible or moderately resistant soft red winter wheat cultivar) for FHB control at four field locations in Illinois from 2011 through 2014. Trial results are reported as probabilities for all model effects and interactions for the concentrations of Fusarium mycotoxins deoxynivalenol (DON), 3-acetyl-DON, 15-acetyl-DON, nivalenol, and zearalenone reported in the straw and grain and the FHB index and yield.

\begin{tabular}{|c|c|c|c|c|c|c|c|c|c|c|}
\hline \multirow[b]{2}{*}{ Effect } & & \multirow[b]{2}{*}{ df } & \multicolumn{2}{|c|}{$\begin{array}{c}\text { Deoxynivalenol } \\
\text { (DON) }\end{array}$} & \multirow{2}{*}{$\frac{\text { 3-acetyl-DON }}{\text { Straw }}$} & \multirow{2}{*}{$\frac{\text { 15-acetyl-DON }}{\text { Straw }}$} & \multirow{2}{*}{$\frac{\text { Nivalenol }}{\text { Straw }}$} & \multirow{2}{*}{$\frac{\text { Zearalenone }}{\text { Straw }}$} & \multirow[b]{2}{*}{ Index ${ }^{a}$} & \multirow[b]{2}{*}{ Yield } \\
\hline & & & Grain & Straw & & & & & & \\
\hline Cultivar & $P>F$ & 1 & 0.05 & 0.02 & 0.12 & 0.02 & 0.56 & 0.34 & 0.29 & 0.42 \\
\hline Fungicide & $P>F$ & 1 & 0.41 & 0.20 & 0.38 & 0.47 & 0.50 & 0.40 & 0.15 & 0.07 \\
\hline Cultivar $\times$ fungicide & $P>F$ & 3 & 0.66 & 0.58 & 0.56 & 0.85 & 0.79 & 0.68 & 0.48 & 0.56 \\
\hline Year & $P>F$ & 3 & 0.12 & $\mathrm{NE}^{\mathrm{b}}$ & 1.00 & $\mathrm{NE}$ & $\mathrm{NE}$ & 0.99 & 0.99 & NE \\
\hline Location & $P>F$ & 3 & 0.72 & 0.43 & 0.23 & 0.12 & 0.99 & 0.93 & 0.99 & 0.06 \\
\hline Year $\times$ location & $P>F$ & 9 & 0.05 & 0.0001 & 0.006 & 0.01 & 1.00 & 0.15 & 0.40 & 0.35 \\
\hline Year $\times$ cultivar & $P>F$ & 9 & 0.16 & 0.13 & 0.88 & 0.60 & $\mathrm{NE}$ & $\mathrm{NE}$ & 0.26 & 0.59 \\
\hline Year $\times$ location $\times$ cultivar & $P>F$ & 9 & 0.0001 & 0.52 & $\mathrm{NE}$ & 0.56 & 0.12 & 0.94 & 0.53 & $<0.0001$ \\
\hline Year $\times$ cultivar $\times$ fungicide & $P>F$ & 9 & 0.47 & 0.68 & 0.01 & 0.40 & 0.33 & 0.75 & 0.0004 & 0.72 \\
\hline
\end{tabular}

${ }^{a}$ Index was calculated by (FHB incidence $\times$ FHB severity) $/ 100$.

b Not estimable: did not contribute to the variability of the model. 
to preserve its end use quality; however, in the current study, significant reductions in DON concentration in the straw or grain were not observed through the application of DMI fungicides compared with nontreated control plots.

Fungicide efficacy is affected by the level of disease resistance of a cultivar, presence of inoculum, and favorable weather conditions (Paul et al. 2010). Mesterházy (1995) and Mesterházy et al. (1999) observed that, in years with low FHB disease pressure, the percent reduction in FHB by applying a fungicide was higher than in years with moderate or high FHB disease pressure. A diminished efficacy of DMI fungicides was observed in this study and was likely a result of high FHB index, especially in 2013 and 2014. From the present study, it can be interpreted that, in years with high FHB index, the application of a DMI fungicide did not sufficiently reduce DON concentration in the grain. It was also observed that the application of a QoI fungicide could potentially increase DON concentration in the straw compared with not using a fungicide, a situation that could be extremely detrimental in operations where wheat straw is baled for livestock bedding.

The use of QoI fungicides is generally not recommended for the control of Fusarium mycotoxins due to their potential to increase total DON concentration in the grain. Increases in DON concentration in the grain after the application of QoI fungicides have been consistently reported (Blandino et al. 2006; Magan et al. 2002; Pirgozliev et al. 2002; Simpson et al. 2001; Zhang et al. 2009). To our knowledge, no researchers have reported the impact of QoI fungicides on DON concentration in the straw. In the current study, applications of DMI and QoI fungicides did not result in significantly different levels of DON versus nontreated control plots. Significant increases were observed in the straw when QoI-containing fungicides were applied over the application of certain DMI fungicides. This observed increase in DON in the straw following applications of QoI fungicides raises more important questions as to why QoI fungicides may increase total DON concentration. The mechanism behind the increase in DON concentration in straw when using QoI fungicides is unknown; however, researchers have speculated that observed increases of DON in grain with QoI fungicides may be related to changing the ratio between toxigenic and non-toxigenic fungi, increasing infection of Fusarium spp. due to a reduction of other fungal pathogens on the head, or increasing DON production in response to a QoI fungicide (D'Mello et al. 2001; Magan et al. 2002; Pirgozliev et al. 2003).

Although generally not adequately effective for the control of FHB and the mycotoxins that result from head infection, QoI fungicides are used to control many different foliar diseases of small grain cereals. QoI fungicides inhibit spore germination and exhibit translaminar movement through the leaf allowing them to be locally

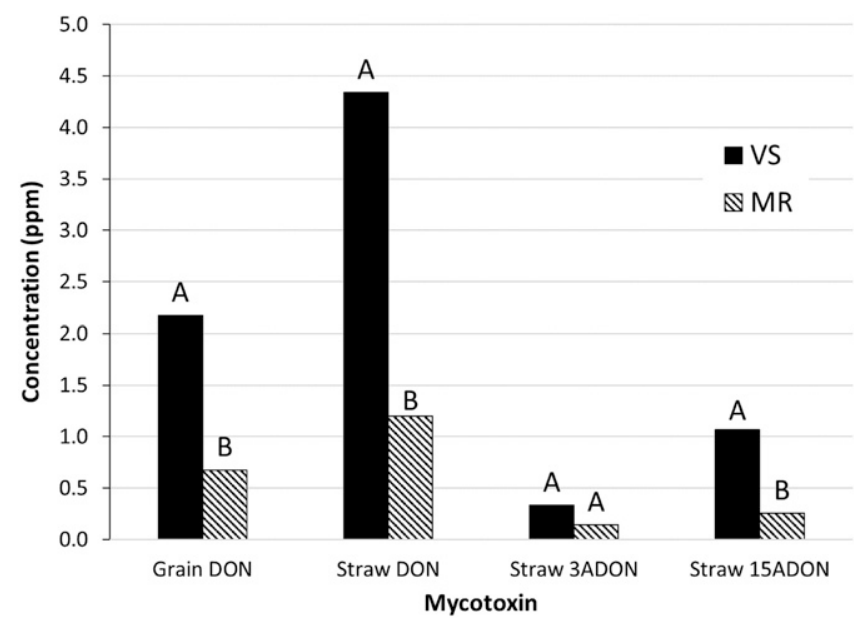

Fig. 2. Estimated mycotoxin concentrations in the straw and grain reported as parts per million (ppm) across all years for the integrated management study. Values are the back-transformed concentrations for each mycotoxin in the indicated plant material. Letters indicate significant differences between cultivars within each mycotoxin and plant part (grain or straw) using Tukey's W test with $\alpha=0.05$. systemic, ideal for the management of many foliar diseases. These diseases include stripe rust (caused by Puccinia striiformis), leaf rust (caused by $P$. triticina), black stem rust (caused by $P$. graminis), Stagonospora (caused by Parastagononospora nodorum) and Septoria (caused by Zymoseptoria tritici) leaf blotches, and tan spot (caused by Pyrenophora tritici-repentis), which are diseases of economic importance throughout many major wheat growing regions. The application of QoI fungicides to control these foliar diseases has the possibility of resulting in higher DON concentration in straw than if DMI fungicides were applied for FHB control. In this study, consistently higher DON concentrations were observed in the straw than in the grain, regardless of the fungicide or whether or not a fungicide was applied, meaning that low DON concentrations in the grain may not be an indication of low DON concentrations in the straw.

Several studies have reported poor correlations between total DON concentration in the grain and FHB index (Bai et al. 2001; Haidukowski et al. 2005; Mesterházy et al. 2003). In the current study, a significant, positive correlation was observed between DON concentration in the grain and FHB index and between DON concentration in the straw and FHB index. These correlations, though significant, had low correlation coefficients. Visual characteristics such as disease incidence and disease severity are used to evaluate the effectiveness of fungicides for controlling FHB in the grain and predicting DON concentrations in the grain; however, visual characteristics are often poor indicators of FHB control and DON reduction in straw, making it exceptionally hard to evaluate the effectiveness of a fungicide in its ability to minimize mycotoxin concentrations in the straw, short of DON testing.

Several studies have also indicated that the environment has a significant impact on disease development (D'Angelo et al. 2014; Paul et al. 2008, 2010; Wegulo et al. 2013). These studies have indicated that even the most effective forms of controlling FHB through cultivar selection and fungicide application can still result in a high FHB index and significant DON concentration if conditions are favorable for $F$. graminearum infection and FHB development. The resistance or susceptibility of a cultivar, though largely impacted by its genetics, can also be influenced by the environment and FHB disease pressure (Miedaner et al. 2001; Schroeder and Christensen 1963; Wegulo et al. 2013). Many studies have indicated that fungicide efficacy is generally higher with moderately resistant cultivars than it is with susceptible cultivars (Amarasinghe et al. 2013; Wegulo et al. 2011, 2013; Willyerd et al. 2012). In these studies, significantly lower DON concentrations were observed in the grain of the fungicidetreated plots over the nontreated control plots. Results from the current study support that the environment impacts the effectiveness of management practices on DON levels in both the grain and the straw, as a significant interaction was observed between location and year in both studies. Rainfall accumulation from 1 April to 30 June for each year and location is reported in Table 1, and was highly variable for each location across years. Rainfall accumulation was especially low for all locations in 2012. Although it is only one environmental factor

Table 5. Results of a Spearman correlation analysis for the integrated disease management trial showing the correlation coefficients and probabilities of the correlations between the deoxynivalenol (DON), 3-acetyl-DON (3ADON), and 15-acetyl-DON (15ADON) concentrations reported in the straw with the DON concentrations in the grain, the Fusarium head blight (FHB) index value, and the yield levels in the integrated management study. Correlations between the DON concentrations in the grain and the FHB index and yield are also listed.

\begin{tabular}{|c|c|c|c|c|c|}
\hline & & \multicolumn{2}{|c|}{ DON } & \multirow{2}{*}{$\frac{\text { 3ADON }}{\text { Straw }}$} & \multirow{2}{*}{$\frac{\text { 15ADON }}{\text { Straw }}$} \\
\hline & & Grain & $\overline{\text { Straw }}$ & & \\
\hline \multirow[t]{2}{*}{ Grain DON } & $\mathrm{R}$ & - & 0.67 & 0.62 & 0.62 \\
\hline & Prob $>|r|$ & - & $<0.0001$ & $<0.0001$ & $<0.0001$ \\
\hline \multirow[t]{2}{*}{ Index ${ }^{a}$} & $\mathrm{R}$ & 0.61 & 0.52 & 0.49 & 0.47 \\
\hline & Prob $>|r|$ & $<0.0001$ & $<0.0001$ & $<0.0001$ & $<0.0001$ \\
\hline \multirow[t]{2}{*}{ Yield } & $\mathrm{R}$ & -0.23 & -0.06 & -0.17 & -0.04 \\
\hline & Prob $>|r|$ & 0.0007 & 0.38 & 0.01 & 0.57 \\
\hline
\end{tabular}

${ }^{\mathrm{a}}$ Index was calculated by (FHB incidence $\times$ FHB severity) $/ 100$. 
that could affect disease and DON levels, the variability in rainfall across locations and years could help partially explain the observed significant interactions between location and year. Anthesis dates for each location were similar across years, except for 2012. Anthesis dates occurred much earlier in 2012, which was an indication of warmer temperatures occurring that year that advanced wheat growth and development rate.

By using integrated disease management approaches, significant reductions in mycotoxin concentrations in both the grain and the straw, based on the resistance level of a cultivar, were observed in this study. The application of a fungicide did not result in significant reductions in DON concentration within a cultivar as compared with the plants that were not treated with a fungicide. This observation is consistent with what was found in the fungicide study, and is consistent with the idea that the use of resistant cultivars can offer effective control of DON concentration in the grain and the straw (Miller et al. 1985; Willyerd et al. 2012). The study by Miller et al. (1985) was one of the first to evaluate the impact of cultivar resistance on DON reduction in both the grain and in straw, coming shortly after the discovery and integration of more effective forms of resistance to mycotoxin accumulation in the grain (Liu 1985). Miller et al. (1985) reported that the susceptible cultivar, even when treated with a fungicide, had significantly higher concentrations of DON in both the straw and the grain, as compared with the levels found in the untreated, moderately resistant cultivar. Research by Willyerd et al. (2012) also showed that the use of a moderately resistant cultivar, even with no fungicide treatment, offered better control of DON accumulation in the grain than did the use of a susceptible cultivar that was treated with a fungicide. This reinforces the importance of using resistant cultivars in integrated disease management approaches for the reduction of mycotoxins in both the grain and the straw.

The observed correlation between DON levels in the grain and DON levels in the straw in this study may be useful in developing a better understanding of how to best control the accumulation of Fusarium-associated mycotoxins in the straw. The current study supports the idea that the use of moderately resistant cultivars results in significant reductions in DON concentrations in grain and straw, regardless of whether or not a fungicide is applied. Significantly higher DON concentrations were found in the susceptible cultivar, with or without the application of a fungicide, when compared with the levels found in the moderately resistant cultivar, regardless of the fungicide treatment. This may indicate that there is a relationship between cultivar resistance and reducing DON concentration in the straw.

Of note is the first documented report of the mycotoxin 3ADON recovered from Fusarium-contaminated wheat in Illinois. With the establishment of the more aggressive 3ADON chemotype in parts of the United States and Canada (Puri and Zhong 2010; Ward et al. 2008), the isolation of $3 \mathrm{ADON}$ from the straw in this study begs the question of whether or not the $3 \mathrm{ADON}$ chemotype of $F$. graminearum is present in Illinois. Isolates of the 3ADON chemotype are capable of producing up to four times more DON than isolates of the 15ADON chemotype (Puri and Zhong 2010). If 3ADON-producing isolates of $F$. graminearum are present in Illinois, this may account for the high levels of DON observed in the straw and the grain in this study. A comprehensive survey of $F$. graminearum chemotypes in Illinois is needed to confirm this hypothesis. Regardless of the chemotype, management tactics to minimize FHB symptoms and reduce DON accumulation in the grain remain the same.

Ultimately, the goals of optimal management of FHB are to reduce DON levels, increase yield, and minimize Fusarium-damaged kernels. All of these factors contribute to the economic impacts of FHB and make the need for effective management strategies exceptionally important. Salgado et al. (2014) emphasized weighing the economic impacts of applying fungicides and integrating cultivar resistance against the potential reduction of FHB damage and mycotoxin concentrations in the grain. Wheat straw is no different in terms of the need for effective management of the accumulation of mycotoxins associated with FHB when used as bedding material. The use of wheat straw in swine production for bedding increases the risk of exposure of swine to DON. Baling straw contaminated with mycotoxins as a result of
$F$. graminearum infection can have negative economic implications to growers because of its lack of salability as bedding material. The cost of fungicide applications and resistant cultivar selection must be weighed against the potential of economic return to determine if they are feasible options to control DON in the straw.

\section{Acknowledgments}

The authors would like to thank Y. Dong at the University of Minnesota Mycotoxin Testing Laboratory, A. Krill, N. Smith, E. Adee, B. Mansfield, M. Johnson, S. Ebelhar, J. Pike, L. Deal, and R. Bellm for their assistance with field trials, and numerous summer workers and lab members for their assistance in collecting and processing grain and straw samples.

\section{Literature Cited}

Amarasinghe, C. C., Tamburic-Ilinic, L., Gilbert, J., Brulé-Babel, A., and Fernando, W. G. D. 2013. Evaluation of different fungicides for control of Fusarium head blight in wheat inoculated with 3ADON and 15ADON chemotypes of Fusarium graminearum in Canada. Can. J. Plant Pathol. 35: 200-208.

Bai, G., Plattner, R. D., Desjardins, A. E., and Kolb, F. L. 2001. Resistance to Fusarium head blight and deoxynivalenol accumulation in wheat. Plant Breed. 120:1-6.

Blandino, M., Haidukowski, M., Pascale, M., Plizzari, L., Scudellari, D., and Reyneri, A. 2012. Integrated strategies for the control of Fusarium head blight and deoxynivalenol contamination in winter wheat. Field Crops Res. 133: 139-149.

Blandino, M., Minelli, L., and Reyneri, A. 2006. Strategies for the chemical control of Fusarium head blight: Effect on yield, alveographic parameters and deoxynivalenol contamination in winter wheat grain. Eur. J. Agron. 25:193-201.

Boyacioglu, D., Hettiarachchy, N. S., and Stack, R. W. 1992. Effect of three systemic fungicides on deoxynivalenol (vomitoxin) production by Fusarium graminearum in wheat. Can. J. Plant Sci. 72:93-101.

Brinkmeyer, U., Dänicke, S., Lehmann, M., Valenta, H., Lebzien, P., Schollenberger, M., Südekum, K.-H., Weinert, J., and Flachowsky, G. 2006. Influence of a Fusarium culmorum inoculation of wheat on the progression of mycotoxin accumulation, ingredient concentrations and ruminal in sacco dry matter degradation of wheat residues. Arch. Anim. Nutr. 60:141-157.

Chala, A., Weinert, J., and Wolf, G. A. 2003. An integrated approach to the evaluation of the efficacy of fungicides against Fusarium culmorum, the cause of Fusarium head blight of wheat. J. Phytopathol. 151:673-678.

Cowger, C., and Arellano, C. 2013. Fusarium graminearum infection and deoxynivalenol concentrations during development of wheat spikes. Phytopathology 103:460-471.

Cromey, M. G., Lauren, D. R., Parkes, R. A., Sinclair, K. I., Shorter, S. C., and Wallace, A. R. 2001. Control of Fusarium head blight of wheat with fungicides. Australas. Plant Pathol. 30:301-308.

Cromey, M. G., Shorter, S. C., Lauren, D. R., and Sinclair, K. I. 2002. Cultivar and crop management influences on fusarium head blight and mycotoxins in spring wheat (Triticum aestivum) in New Zealand. N. Z. J. Crop Hortic. Sci. 30: 235-247.

Cundliffe, E., Cannon, M., and Davies, J. 1974. Mechanism of inhibition of eukaryotic protein synthesis by trichothecene fungal toxins. Proc. Natl. Acad. Sci. USA 71:30-34.

Cundliffe, E., and Davies, J. E. 1977. Inhibition of initiation, elongation, and termination of eukaryotic protein synthesis by trichothecene fungal toxins. Antimicrob. Agents Chemother. 11:491-499.

D’Angelo, D. L., Bradley, C. A., Ames, K. A., Willyerd, K. T., Madden, L. V., and Paul, P. A. 2014. Efficacy of fungicide applications during and after anthesis against Fusarium head blight and deoxynivalenol in soft red winter wheat Plant Dis. 98:1387-1397.

D’Mello, J. P. F., McDonald, A. M. C., and Rinna, R. 2001. Effect of azoxystrobin on mycotoxin production in a carbendazim-resistant strain of Fusarium sporotrichioides. Phytoparasitica 29:431-440.

Gale, L. R., Harrison, S. A., Ward, T. J., O'Donnell, K., Milus, E. A., Gale, S. W., and Kistler, H. C. 2011. Nivalenol-type populations of Fusarium graminearum and $F$. asiaticum are prevalent on wheat in southern Louisiana. Phytopathology 101:124-134.

Gautam, P., and Dill-Macky, R. 2012. Free water can leach mycotoxins from Fusarium-infected wheat heads. J. Phytopathol. 160:484-490.

Häggblom, P., and Nordkvist, E. 2015. Deoxynivalenol, zearalenone, and Fusarium graminearum contamination of cereal straw; field distribution; and sampling of big bales. Mycotoxin Res. 31:101-107.

Haidukowski, M., Pascale, M., Perrone, G., Pancaldi, D., Campagna, C., and Visconti, A. 2005. Effect of fungicides on the development of Fusarium head blight, yield and deoxynivalenol accumulation in wheat inoculated under field conditions with Fusarium graminearum and Fusarium culmorum. J. Sci. Food Agric. 85:191-198.

Harris, L. J., Desjardins, A. E., Plattner, R. D., Nicholson, P., Butler, G., Young, J. C., Weston, G., Proctor, R. H., and Hohn, T. M. 1999. Possible role of trichothecene mycotoxins in virulence of Fusarium graminearum on maize. Plant Dis. 83:954-960. 
Large, E. 1954. Growth stages in cereals illustration of the Feekes scale. Plant Pathol. 3:128-129.

Liu, Z. Z. 1985. Recent advances in research on wheat scab in China. Pages 169-173 in: Wheat for More Tropical Environments. R. L. Villareal and A. R. Klatt, eds. CIMMYT, D.F., Mexico.

Magan, N., Hope, R., Colleate, A., and Baxter, E. S. 2002. Relationship between growth and mycotoxin production by Fusarium species, biocides and environment. Eur. J. Plant Pathol. 108:685-690.

Marasas, W. F. O., van Rensburg, S. J., and Mirocha, C. J. 1979. Incidence of Fusarium species and the mycotoxins, deoxynivalenol and zearalenone, in corn produced in esophageal cancer areas in Transkei. J. Agric. Food Chem. 27:1108-1112.

McMullen, M., Halley, S., Schatz, B., Meyer, S., Jordahl, J., and Random, J. 2008. Integrated strategies for Fusarium head blight management in the United States. Cereal Res. Commun. 36 (Supplement 6):563-568.

Mesterházy, Á. 1995. Types and components of resistance to Fusarium head blight of wheat. Plant Breed. 114:377-386.

Mesterházy, Á., and Bartók, T. 1996. Control of Fusarium head blight of wheat by fungicides and its effects on the toxin contamination of the grains. PflanzenschutzNachrichten Bayer (English Ed.). 49:181-198.

Mesterházy, Á., Bartók, T., and Lamper, C. 2003. Influence of wheat cultivar, species of Fusarium, and isolate aggressiveness on the efficacy of fungicides for control of Fusarium head blight. Plant Dis. 87:1107-1115.

Mesterházy, Á., Bartók, T., Mirocha, C. G., and Komoróczy, R. 1999. Nature of wheat resistance to Fusarium head blight and the role of deoxynivalenol for breeding. Plant Breed. 118:97-110.

Miedaner, T., Reinbrecht, C., Lauber, U., Scollenberger, M., and Geiger, H. H. 2001. Effects of genotype and genotype-environment interaction on deoxynivalenol accumulation and resistance to Fusarium head blight in rye, triticale, and wheat. Plant Breed. 120:97-105.

Miller, J. D., Young, J. C., and Sampson, D. R. 1985. Deoxynivalenol and Fusarium head blight resistance in spring cereals. Phytopathol. Z. 113:359-367.

Mirocha, C. J., Christensen, C. M., and Nelson, G. H. 1967. Estrogenic metabolite produced by Fusarium graminearum in stored corn. Appl. Microbiol. 15: 497-503.

Nafziger, E. 2009. Small grains and grain sorghum. Pages 37-47 in: Illinois Agronomy Handbook, $24^{\text {th }}$ ed. University of Illinois Extension, Urbana, IL.

Nordkvist, E., and Häggblom, P. 2014. Fusarium mycotoxin contamination of cereals and bedding straw at Swedish pig farms. Anim. Feed Sci. Technol. 198:231-237.

Paul, P. A., Lipps, P. E., Hershman, D. E., McMullen, M. P., Draper, M. A., and Madden, L. V. 2008. Efficacy of triazole-based fungicides for Fusarium head blight and deoxynivalenol control in wheat: a multivariate meta-analysis. Phytopathology 98:999-1011.

Paul, P. A., McMullen, M. P., Hershman, D. E., and Madden, L. V. 2010. Meta-analysis of the effects of triazole-based fungicides on wheat yield and test weight as influenced by Fusarium head blight intensity. Phytopathology 100:160-171.

Pirgozliev, S. R., Edwards, S. G., Hare, M. C., and Jenkinson, P. 2002. Effect of dose rate of azoxystrobin and metconazole on the development of Fusarium head blight and the accumulation of deoxynivalenol (DON) in winter wheat grain. Eur. J. Plant Pathol. 108:469-478.

Pirgozliev, S. R., Edwards, S. G., Hare, M. C., and Jenkinson, P. 2003. Strategies for the control of Fusarium head blight in cereals. Eur. J. Plant Pathol. 109:731-742.

Puri, K. D., and Zhong, S. 2010. The 3 ADON population of Fusarium graminearum found in North Dakota is more aggressive and produces a higher level of DON than the prevalent $15 \mathrm{ADON}$ population in spring wheat. Phytopathology 100: 1007-1014.

Rohweder, D., Kersten, S., Valenta, H., Sondermann, S., Schollenberger, M., Drochner, W., and Dänicke, S. 2013. Bioavailability of the Fusarium toxin deoxynivalenol (DON) from wheat straw and chaff in pigs. Arch. Anim. Nutr. 67:37-47.
Rohweder, D., Valenta, H., Sondermann, S., Schollenberger, M., Drochner, W. Pahlow, G., Döll, S., and Dänicke, S. 2011. Effect of different storage conditions on the mycotoxin contamination of Fusarium culmorum -infected and non-infected wheat straw. Mycotoxin Res. 27:145-153.

Rottinghaus, G. E., Tacke, B. K., Evans, T. J., Mostrom, M. S., Sweets, L. E., and McKendry, A. L. 2009. Fusarium mycotoxin concentrations in the straw, chaff, and grain of soft red winter wheats expressing a range of resistance to Fusarium head blight. Page 10 in: Proceedings of the 2009 National Fusarium Head Blight Forum, Orlando, FL. S. Canty, A. Clark, J. Mundell, E. Walton, D. Ellis, and D. Van Sanford, eds. University of Kentucky, Lexington, KY.

Salgado, J. D., Madden, L. V., and Paul, P. A. 2014. Efficacy and economics of integrating in-field and harvesting strategies to manage Fusarium head blight of wheat. Plant Dis. 98:1407-1421.

Schroeder, H. W., and Christensen, J. J. 1963. Factors affecting resistance of wheat to scab caused by Gibberella zeae. Phytopathology 53:831-838.

Shaner, G. 2003. Epidemiology of Fusarium head blight of small grain cereals in North America. Pages 84-119 in: Fusarium Head Blight of Wheat and Barley. K. J. Leonard and W. R. Bushnell, eds. American Phytopathological Society Press, St. Paul, MN.

Simpson, D. R., Weston, G. E., Turner, J. A., Jennings, P., and Nicholson, P. 2001 Differential control of head blight pathogens of wheat by fungicides and consequences for mycotoxin contamination of grain. Eur. J. Plant Pathol. 107:421-431.

Sutton, J. C. 1982. Epidemiology of wheat head blight and maize ear rot caused by Fusarium graminearum. Can. J. Plant Pathol. 4:195-209.

Tanaka, H., Takino, M., Sugita-Konishi, Y., and Tanaka, T. 2006. Development of a liquid chromatography/time-of-flight mass spectrometric method for the simultaneous determination of trichothecenes, zearalenone and aflatoxins in foodstuffs. Rapid Commun. Mass Spectrom. 20:1422-1428.

van Barneveld, R., Edwards, T., and Choct, M. 2005. Accurate assessment of diet intake and composition in various pig housing systems. APL Project 1754. Australian Pork Ltd, Barton, ACT, Australia.

Vesonder, R. F., and Hesseltine, C. W. 1981. Vomitoxin: Natural occurrence on cereal grains and significance as a refusal factor and emetic factor to swine. Process Biochem. 16:12-15.

Ward, T. J., Clear, R. M., Rooney, A. P., O’Donnell, K., Gaba, D., Patrick, S. Starkey, D. E., Gilbert, J., Geiser, D. M., and Nowicki, T. W. 2008. An adaptive evolutionary shift in Fusarium head blight pathogen populations is driving the rapid spread of more toxigenic Fusarium graminearum in North America. Fungal Genet. Biol. 45:473-484.

Wegulo, S. N., Bockus, W. W., Hernandez Nopsa, J., De Wolf, E. D., Eskridge, K. M. Peiris, K. H. S., and Dowell, F. E. 2011. Effects of integrating cultivar resistance and fungicide application on Fusarium head blight and deoxynivalenol in winter wheat. Plant Dis. 95:554-560.

Wegulo, S. N., Bockus, W. W., Nopsa, J. F. H., Peiris, K. H. S., and Dowell, F. E. 2013. Integration of fungicide application and cultivar resistance to manage Fusarium head blight in wheat. Pages 35-54 in: Fungicides - Showcases of Integrated Plant Disease Management from Around the World. M. Nita, ed Intech, Rijeka, Croatia.

Willyerd, K. T., Li, C., Madden, L. V., Bradley, C. A., Bergstrom, G. C., Sweets, L. E., McMullen, M., Ransom, J. K., Grybauskas, A., Osborne, L., Wegulo, S. N., Hershman, D. E., Wise, K., Bockus, W. W., Groth, D., Dill-Macky, R., Milus, E., Esker, P. D., Waxman, K. D., Adee, E. A., Ebelhar, S. E., Young, B. G., and Paul, P. A. 2012. Efficacy and stability of integrating fungicide and cultivar resistance to manage Fusarium head blight and deoxynivalenol in wheat. Plant Dis. 96:957-967.

Zhang, Y. J., Fan, P. S., Zhang, X., Chen, C. J., and Zhou, M. G. 2009 Quantification of Fusarium graminearum in harvested grain by real-time polymerase chain reaction to assess efficacies of fungicides on Fusarium head blight, deoxynivalenol contamination, and yield of winter wheat Phytopathology 99:95-100. 